\title{
Factors Influencing Consumer Behavior: A Study among University Students in Malaysia
}

\author{
Rajennd Muniady $^{1}$, Abdullah Al- Mamun ${ }^{1}$, P. Yukthamarani Permarupan ${ }^{1} \&$ Noor Raihani Binti Zainol ${ }^{1}$ \\ ${ }^{1}$ Faculty of Entrepreneurship and Business, Universiti Malaysia Kelantan, Pengkalan Chepa, Kota Bharu, \\ Malaysia \\ Correspondence: Abdullah Al- Mamun, Faculty of Entrepreneurship and Business, Universiti Malaysia Kelantan, \\ Pengkalan Chepa, 16100 Kota Bharu, Kelantan, Malaysia. E-mail: abdullah.a@umk.edu.my
}

Received: July 29, 2013 Accepted: March 19, 2014 Online Published: April 29, 2014

doi:10.5539/ass.v10n9p18 URL: http://dx.doi.org/10.5539/ass.v10n9p18

\begin{abstract}
The objective of this study is to examine how personal factors such as lifestyle, personality, and economic situations affect the consumer behavior of Malaysian university students. A quantitative approach was adopted and a self-administered questionnaire was distributed to collect data from university students. Findings illustrate that 'personality' influences the consumer behavior among Malaysian university student. This study also noted that the economic situation had a negative relationship with consumer behavior. Findings of this study improve our understanding of consumer behavior of Malaysian University Students. The findings of this study provide valuable insights in identifying and taking steps to improve on the services, ambience, and needs of the student segment of the Malaysian market.
\end{abstract}

Keywords: lifestyle, personality, economic condition, consumer behavior, university students

\section{Introduction}

Market segmentation is a crucial element in marketing. Products can no longer be manufactured and sold without taking into account the consumer needs and appreciating the heterogeneity of those needs (Wedel \& Kamakura, 2000). The earliest attempts of market segmentation were based on demographics. While there are many other ways to recognize a market, to date, the placements of products and services are still largely based on demographic factors of consumers. Demographic segmentation remains popular because of the possible correlation between demographic factors and specialized consumer activities such as buying and shopping. Products such as personal care and clothing are specifically designed, targeted, and promoted with either men or women in mind. The ability to easily measure and a very well defined demographic category contributes to the popularity of demographic segmentations (Pol, 1991). On top of that, there is readily available data on demographics from government agencies, which is reliable; this helps a lot in segmenting potential customers.

Today, decision-making has become more complex and is considered very important for consumers. This is due to the rapid change of the competitive global business environment. Consumers are being exposed to advertising campaigns, news sources, and direct mailing that feed abundant information; most of it has too many mixed messages. On top of that, the increasing number and choices of goods, retail outlets, and shopping malls, and the availability of multi-component products and electronic purchasing facility have broadened the sphere for consumer choices. This makes decision making more complicated (Hafstrom et al., 1992).

In addition, nowadays, there are more sophisticated and complex products, reducing inter-brand differences, and elevating counterfeits and products that look alike, therefore, some consumers feel overwhelmed and find it difficult to decide (Mitchell, 2001). Profiling consumers' decision-making process focuses on studies of the majority of consumer interests (Sproles, 1985). Consumer affairs professionals use such profiles to understand consumers' shopping behavior, while advertisers and marketing researchers use them to segment the consumers into various segments for product positioning (Srinivas, Steven \& Andrews, 1993).

Understanding consumer decision-making is very important for companies and marketers in coming up with appropriate marketing strategies to suit their target groups. In this relation, personal factors, such as age and lifestyle stage, economic situation, occupation, lifestyle, personality, and self-concept have been identified in many literatures on the theme of consumer shopping behavior as a significant element in understanding 
consumer behavior (Kotler \& Armstrong, 2006). It has also been identified as a fundamental marketing segmentation indicator for companies to meet their customers' needs and wants. Therefore, marketers should always strive to understand the differences and similarities in decision-making styles.

University students represent an important segment of shoppers among the Malaysian consumer segments. Based on the size and characteristics of the market, university students are one of the most crucial markets for many businesses (Wong \& Smith, 2002). White (2001) stated that the student market is a significant segment for marketers to reach and get feedback from, due to the fact that they are constantly faced with a lot of life decisions, including many first time purchase decisions without the influence of the parents. Very few researches have been carried out to better understand this group of consumers. Understanding this group, especially their shopping behavior, is important for marketers to develop strategies to target them. This study therefore intends to examine whether personal factors such as lifestyle, lifecycle stage, personality, and economic situations determine consumer behavior of Malaysian university students. This study focuses on personal factors such as economic situation, lifestyle, lifecycle stage, personality, and tries to understand the relation and effect that this five variables have on the consumer behavior of Malaysian students.

\section{Literature Review}

Today's shopping malls and centres are extensively planned and managed. A considerable amount of consumer research contributes to this planning and it is used to suggest how to place stores in an optimal arrangement within the shopping centres. The goal is a business setting that increases the economic performance of the individual businesses and ultimately the shopping centres as a whole.

Retailers are becoming more sophisticated in applying their marketing strategies, but they also have the need to understand the impact of their advertising and promotional activities on their retail brands. In the meantime, the growth of category management has changed the way retailers view and manages their businesses in recent years. This process is created to grow more categories by attracting new customers and increasing repeat purchases amongst existing customers through efficient ranging, shelf management, promotions, and replenishments.

Malaysian retail remains dominated by store-based retailers despite the strong growth in the small non-store market, and it is the developments within store-based channels that have been largely driving the market growth. During the 2002-2007 period, Malaysia became increasingly urbanized, leading to a shift in consumer shopping behaviour, which benefited modern, larger-scaled retail channels such as hypermarkets and par pharmacies/drugstores, while convenience stores also performed well. Urban consumers typically spend 1.5 times as much as their rural counterparts, so this change of lifestyle has resulted in a major increase in retail sales; however, traditional channels, less suited to urban environments, have seen revenues slide sharply. Malaysia's fifty-seven years of independence also marks another milestone in its economic development. After independence, the nation was highly dependent on tin and rubber and more than half of the population was under the poverty line. Today, Malaysia has a broad-based and very well diversified economy. Malaysia is the $19^{\text {th }}$ largest trading nation in the world, having a trade excess of RM 1 trillion.

With the existence of marketing "know-how" and internet savvy customers coupled with retail concentration trends, there is a lot of competition, which in turn, has generated continuous development and changes in the field of retailing, especially in grocery retailing. According to a few researches that have been carried out by Nielsen.com, firstly, new store settings are increasing the choices available to potential customers, and changing the way they shop, but not always in the same way in every country. In some chains of brands, the top $30-40 \%$ of customers at times account for up to $80 \%$ of total sales volume. The challenge is to change these high spenders' loyal purchasers; and, lastly international retailers are penetrating new markets every year - some with remarkable success, and others still having to find the right formula for their setup.

Understanding human needs is critical for effective targeted marketing. However, these needs are not always easily detectable. Consumers are changing as well as their needs and want, influenced by trends, and internal and external factors.

\subsection{Consumer Behavior}

Consumer behavior involves studies, which look into how people decide to buy things, what they choose to buy, where they prefer to buy it, why, and when they buy it. It is a mix of psychology, sociology, anthropology, and economic elements. It thrives to understand the buyer's decision-making process, both individually and in groups. It focuses on characteristics of individual consumers such as demographics, psychographics, and behavioral elements in an effort to understand people's need and wants. Significant progress has been achieved in identifying the behavioral elements of buying, and a number of theories of buying have been postulated. 
However, less is known about what determines the shopping and consuming behavior. Kotler and Armstrong (2006) suggest that there are determinants such as cultural, social, personal, and psychological factors that shape an individual's consumer behavior. The following part looks into the personal factors, as they are the elements being tested in this research.

\subsection{Economic Situation}

The general buying patterns of consumers tend to alter during an economic crisis. Consumers react to most of the change in the economic situation around them by changing their consumption. This is caused from a change in the levels of consumers' perception of risk. Financial crisis affects most customers not only economically but also psychologically. People become scared to spend and too careful with what they do with their money. They prefer not wanting to spend their money on premium products anymore, even if they can still afford to do so. They tend to only buy what are necessities, switch to low-end brands, and have a more rational view on promotions. They even start to compare different goods and select the best based on price, compromising on the quality. The whole buying process can be changed from being a more limited decision-making buying behavior to become an extensive decision-making buying behavior. In other words, the buying behavior before the crisis was not based on extensive decision-making and information gathering but after the crisis the process has become more complicated.

Growing rate of unemployment, increasing levels of inflation, "freezing" or even decrease in wages, reduction of purchasing power, and an unstable economic situation are factors that affect the consumers in almost all national markets. As long as people are informed about the economic crisis and as long as the press delivers news focused on the crisis's effects, there is a huge psychological and negative impact on consumers (Amalia, 2009). Consumption pattern changes are the reflection and influence of a crisis. Katona (1974) explains that many people believe that when prices get higher in the near future, they would have to spend their money on buying necessities and therefore, be left with smaller resources for the purchase of desirable but non-necessity goods and services. Therefore, an inflation rate discourages discretionary expenditures. Katona (1974) also explains that during a recession period, consumers are motivated to hold on to their money because of possible threats related to their jobs or income.

\subsection{Lifestyle}

The long existing consumer life-styles demonstrate how consumers think, live, act, and behave. This is generally determined by individual consumers' demographic background, experiences, current situation or action, socio-economic characteristics, and behavioral tendencies. This is an attempt to generalize more realistic multi-dimensional clusters of consumers that represent a sub-segment for a particular product/brand. It gives answers to the deeper motivations and aspirations behind the purchase and usage of a product and service (Wansink, 2000).

Since it was introduced by Lazer (1963), consumer life-style study information has become a very popular area in the marketing management's decision-making process. The utilization of values and life-styles as segmentation elements is continuously becoming famous in the hopes that it defines more observed consumer behavioral/action differences instead of relying on pure socio-economic and/or demographic variables. This is because consumer values and life-style characteristics do give a deep view of the market and reflect the consumers themselves. Apart from that, consumer life style data meets the demands of management practice for increasingly sophisticated and useable marketing information (Wagner \& Weddle, 1995).

It was stated that consumers' life-style is a part of inherited individual characteristics that are molded and formed from the social interaction experience as consumers' progress through the family lifecycle (Hawkins et.al 1998). In an effort to distinguish their product/service range, international organizations pay close attention to the dynamic global market segment that is assumed to drive the market forward within the near future. It is suggested that the new globalization trend will grant success for those who constantly make an effort to stay abreast of life-style trends.

\subsection{Personality}

The attribution of human personality traits to products and services leads to the construct of brand personality. A brand is characterized by matching the brand with personality trait dimensions since consumers would often associate their choice of brands with celebrity characters or famous historical figures (McCraken, 1989). The brand personality aspect cannot be easily replicated and the uniqueness of a project gives the holding company a reasonable economic advantage over its competitors (Kim, 2001). Perceived personality of a particular brand provides consumers with the ways to express specific dimensions of their self. This will strengthen the consumer 
self-concept and it is in-line with the symbolic meaning.

a. Self-Concept: Self-concept is a blanket of various potential different identities that may guide human buying behavior. Markus et al. (1985) considered self-concept as a set of self-schemata, which are organized cognitive structures in a certain domain of the self. The structures react depending on the situation at the time. Based on Jamal \& Goode's (2001) work, there is a multiple component perspective of self. Most goods say something about the social world of those who buy them. Therefore, consumers look for goods, which have images matching with their perceptions of self.

b. Self Image Congruity and Consumer Behavior: Self-image congruity affects consumer's purchase motivation because people have a motive to behave consistently with their self perceptions (Epstein, 1980); that is, they prefer goods with characteristics that match their own self-image. Much of the research conducted in terms of consumer goods shows that the greater the match between the brand user image with the consumer's self image, the more likely that consumers implicitly infer that the use of the brand should meet their need for self esteem.

\subsection{Spending Pattern}

Shopping does not always mean that one has to buy the product one prefers. There are, of course, the perennial window shoppers who are just looking around, peering through the glass windows of shops, but buy nothing. People do this to kill time or to think and plan first before buying. Along with the excess of malls being constructed all over the city, a trip to the mall has become a past time for almost everyone especially for women. Shopping is something a woman has to do and likes to do, whether it is shopping for groceries, shopping for fashion, or shopping for the home.

Shopping is a gendered activity and it influences the way they spend. Existing research on buying behaviour seems to suggest women prefer to go shopping and that shopping is labelled as a "female typed" task (South \& Spitze, 1994). For man, shopping is just the same as spending, and for women, shopping is fun. Man will spend their money by focusing on a quick-hit shopping and setting minimum targets of price and product specifications. Once an item with the matching requirements has been found at the right price, shopping is over (Dempsey, 2003). Shopping is also associated with women because it is a natural role for them, that is, buying for the family's needs such as food and clothes and compared to men, women are more patient when it comes to shopping. Women have the patience to go from one retail outlet to another to search for the best product and to get the best offering for their money's worth.

A report shows an overall shift in the spending habits of young, mainly college-aged students, which may be attributed to extra spending money among the young. They spend most of their money in luxurious and branded clothes and bags, accessories, entertainment and dining. Ahmed, Ghinghold and Dahari (2007) also found that Malaysian students spent a large portion of their monthly expenditures in shopping malls and malls are clearly favourites for young adult Malaysians and their money as they are in Western countries. Finally, the committed shoppers segment is primarily female, younger in age, single, with high school education, and with a diverse income level.

\section{Research Methodology}

To fulfill the research objective, this study used the pure quantitative approach. The survey instrument was a self-administered questionnaire. This questionnaire was developed through adaptation from Lumpkin (1985) and Lambert (1979). The questionnaire comprised 2 sections where the first section of the questionnaire covered the demographic details of the students. Demographic variables covered in the study are gender, age, race, marital status, household size, highest educational attainment, monthly income, and its source. In addition, students were also asked on details about their current state of livelihood, such as their present living arrangement and their role, if any, as provider or receiver of daily support in their household. In the second section of the questionnaire, 11 questions on the students' grocery shopping habits were asked. Multiple option choices format was used as responses. In this study, only the consumer behavior related to the purchase of groceries will be explored because food is deemed the second largest single category of household expenditure, highlighting the importance of grocery shopping in a consumer's budget. This has been indicated in the latest household expenditure survey conducted in the period of 2009/10, which showed that Malaysian households spent 20.3 percent of their monthly expenditure on non-alcoholic beverages and food items. Malaysians spent the highest on water, housing, electricity, gas and other fuels ( 22.6 percent), followed by transport (14.9 percent), and on hotels and restaurants (10.9 percent) (Department of Statistics, 2009/10). Section 3 contained 32 questions that tested each independent variable in this study.

For this study, the sampling frame refers to undergraduates from the Binary University College and the Sunway 
University. A student sample was deemed suitable for this research for several reasons. First, student samples have always been found useful for researches that look into the relationship between individual differences and shopping behavior (Calder et al. 1981). Second, current students would have already gained multiple shopping experiences. While they may not have yet experienced major purchases such as a house or a car, they would have had enough multiple experiences in shopping for groceries, music, clothes, electronics, and other discretionary items. A convenience sampling method was employed in this study. Generally, the questionnaires were distributed among students of the Binary University College and the Sunway University. These urban students were also more likely to be active consumers in the marketplace. This group of students was deemed to represent the potentially viable consumers to marketers. Complete data was collected from 248 respondents.

\section{Summary of Findings}

\subsection{Demographic Characteristics of Respondents}

In this survey, there were more female students (61.7 percent) than their male counterparts (38.3 percent). A high proportion of the students was within the age group of $19-24$ years old ( 83.5 percent), followed by those in the age group of $25-30$ (13.3 percent). The smallest contribution came from the age group of $31-36$ (3.2 percent). In terms of ethnic groups, the Indian students dominated at 41.1 percent followed by Chinese (33.9 percent) and Malay (21.8 percent) students. In terms of education level, a majority of students are in the diploma or certificate level. They accounted for 51.2 percent of the sample while students at the degree or professional qualification level accounted for 46.8 percent of the sample. Only 2 percent of the samples were in the postgraduate level.

When the students' present income received was examined, it was found that a majority or 61.3 percent of the students' total income was in the range of less than RM 500 while 15.7 percent reported receiving monthly income in the range of RM 500 - RM 999. This is followed by 13.3 percent of respondents in the range of RM 1000 - RM 1999, and 7.7 percent in the range of RM 2000 - RM 2999. 2 percent of the students reported that they received more than RM 3000 per month. Upon enquiry of the income source, sponsored by parents and scholarship / study loan were among the main sources of income at 48 percent and 34.7 percent, respectively. About 17.3 percent of the students are self-sponsored or working part time for income.

Table 1. Background of the respondents

\begin{tabular}{|c|c|c|c|c|c|}
\hline & $\mathrm{N}$ & $\%$ & & $\mathrm{~N}$ & $\%$ \\
\hline Gender & & & Race & & \\
\hline Male & 95 & 38.3 & Malay & 54 & 21.8 \\
\hline \multirow[t]{2}{*}{ Female } & 153 & 61.7 & Chinese & 84 & 33.9 \\
\hline & & & Indian & 102 & 41.1 \\
\hline Education & & & Others & 8 & 3.2 \\
\hline Diploma & 127 & 51.2 & & & \\
\hline Bachelor & 116 & 46.8 & Age & & \\
\hline \multirow[t]{2}{*}{ Master } & 5 & 2 & $19-24$ & 207 & 83.5 \\
\hline & & & $25-30$ & 33 & 13.3 \\
\hline Monthly Income & & & $31-36$ & 8 & 3.2 \\
\hline Less Than RM 500 & 152 & 61.3 & & & \\
\hline RM500 - RM999 & 39 & 15.7 & Source of Income & & \\
\hline RM1000 - RM1999 & 33 & 13.3 & Scholarship / Study Loan & 86 & 34.7 \\
\hline RM2000 - RM2999 & 19 & 7.7 & Sponsored By Parents & 119 & 48 \\
\hline RM3000 and Above & 5 & 2 & Self-Sponsored / Part Time & 43 & 17.3 \\
\hline
\end{tabular}

\subsection{Reliability Analysis}

Cronbach's alpha is a reliability coefficient that indicates how well the items in a set are positively correlated to one another. The results reported in Table 2 below indicates that Cronbach's Alpha value for Personality, Lifestyle, and Economic Situation is more than 0.6, and therefore, considered as reliable. However, Cronbach's 
Alpha value for Lifestyle Stage is less than the acceptable threshold and therefore, considered not reliable and was not used for further analysis.

Table 2. Summary of reliability analysis

\begin{tabular}{lccr}
\hline Variables & Cronbach's Alpha & N of items & Interpretation \\
\hline Personality & 0.679 & 7 & Moderate \\
Lifestyle & 0.631 & 6 & Moderate \\
Economic Situation & 0.691 & 6 & Moderate \\
Lifecycle Stage & 0.419 & 7 & Poor \\
\hline
\end{tabular}

\subsection{Multiple Regression Analysis}

The F-value of the model, as noted in Table 3, is 6.209 with a $p$-value of 0.000 , which is less than the chosen $5 \%$ level of significance. Thus, confirming the fitness of the model, which indicates that there is a statistically significant relationship between 'consumer behavior' and each of the independent variables namely personality, lifestyle, and economic situation.

Table 3. Model fit

\begin{tabular}{llccccc}
\hline Model & & Sum of Squares & df & Mean Square & F & Sig. \\
\hline 1 & Regression & 3.743 & 3 & 1.248 & 6.209 & $.000^{\mathrm{a}}$ \\
& Residual & 49.034 & 244 & .201 & & \\
& Total & 52.777 & 247 & & \\
\hline
\end{tabular}

The unstandardized and standardized regression coefficients as presented in Table 4 below indicate that personality and economic situation have a significant positive effect on 'Consumer Behavior'. The $p$-value for 'Lifestyle' is more than the chosen $5 \%$ level of significance, and therefore, not statistically significant.

Table 4. Regression coefficients

\begin{tabular}{lccccc}
\hline & \multicolumn{2}{c}{ Unstandardized Coefficients } & \multicolumn{3}{c}{ Standardized Coefficients } \\
& $\mathrm{B}$ & Std. Error & Beta & $\mathrm{t}$ & Sig. \\
\hline (Constant) & 1.568 & .282 & & 5.559 & .000 \\
Personality & .166 & .060 & .192 & 2.754 & .006 \\
Economic Situation & -.152 & .054 & -.185 & -2.825 & .005 \\
Lifestyle & .096 & .056 & .113 & 1.714 & .088 \\
\hline
\end{tabular}

\section{Conclusion}

Based on the outcome of this study, it is evident that students' personality had the most significant effect on consumer behavior compared to their lifestyle and economic condition. This study also noted that the economic situation had a negative relationship with consumer behavior. Findings of this study improve our understanding of consumer behavior of Malaysian University Students.

This study is exploratory and cross-sectional in nature and is by no means an exhaustive study on the students' market. Additionally, the results only reflect the response from limited student consumers in the urban, i.e., students of the Binary University College and the Sunway University. Further measures for this study to be conducted on a national basis would be beneficial, i.e. research to include rural areas and smaller towns and with a bigger sample size to reflect the demographic composition of Malaysia. 
Apart from the personal factor, there are other factors such as cultural factors, social factors, and psychological factors to be considered in determining what affects student's consumer behavior. There is also a need to investigate the extent of 'friendliness' of the retail stores to students. Research in this area of retail store attributes from the perspective of the stores would be able to highlight to consumers on which stores actually cater to the attributes required by student consumers. This research can also look into the storeowners' views on the attributes required by students' consumers as the requirements to provide services for student consumers, which would mean a change in store outlook that might affect their businesses.

Another area of improvement to this study is to segment the student consumers based on their lifestyle activities. In this research, the student consumers' other leisure activities can be identified and their lifestyles can be understood better. Marketers can then incorporate the other activities of interest to these consumers when formulating the marketing programs to make the promotions more interesting. Further extension in this area such as the non-food purchase behavior of student consumers can be studied. Areas of interest would be apparel shopping and the purchase of books and stationary. With such a study, the coverage on the shopping orientations of student consumers will be more complete.

Therefore, based on the findings, consumers search for products, which have images compatible to their perceptions of self. This will reinforce the consumer's self-concept and it is consistent with the symbolic meaning. Consumers buy products not for what they can do, but also for what they mean. In line with that, store or brand owners and managers whose target market is university students should strive to maintain their store or brand image and ambience in consistence with current trends and icons, which reflect the younger generation.

\section{References}

Aaker, J. L. (1997). Dimensions of brand personality. Journal of Marketing Research, 36, 346-356.

Ahmed, Z. U., Ghingold, M., \& Dahari, Z. (2007). Malaysian shopping mall behavior: An exploratory study. Asia Pacific Journal of Marketing and Logistics, 19(4), 331-348. http://dx.doi.org/10.1108/13555850710827841

Calder, B. J., Lynn, W. P., \& Tybout, A. M. (1981). Designing Research for Application. Journal of Consumer Research, 8(2), 197-207. http://dx.doi.org/10.1086/208856

Epstein, S. (1980). The Self Concept: A Review and the Proposal of an Integrated Theory of Personality. In E. Staub (Ed.), Personality Basic Issues and Current Research (pp. 82-132). Englewood Cliffs, NJ: Prentice-Hall.

Hafstrom, J. L., Chae, J. S., \& Chung, Y. S. (1992). Consumer Decision Making Styles: Comparison between United States and Korean Young Consumers. The Journal of Consumer Affairs, 26(1), 146-159. http://dx.doi.org/10.1111/j.1745-6606.1992.tb00020.x

Hawkins, D. I., Best, R. J., \& Kenneth, C. A. (1998). Consumer Behavior Building Marketing Strategy. Irwin/McGraw-Hill.

Jamal, A., \& Goode, M. (2001). Consumers and Brands: A study of the Impact of self-image congruence on brand preference and satisfaction. Marketing Intelligence \& Planning, 19(7), 482. http://dx.doi.org/10.1108/02634500110408286

Katona, G. (1974). Psychology and Consumer Economics. Journal of Consumer Research, 1, 1-8. http://dx.doi.org/10.1086/208575

Kim, Y. K. (2001). The study on the dimensions of eBrand personality and its determinants. Journal of Korean Society for Journalism and Communication Study, 45, 229-426.

Kotler, P., \& Armstrong, G. (2006). Principles of Marketing (pp. 136-151).

Lambert, Z. V. (1979). An Investigation of Older Consumers' Unmet Needs and Wants at the Retail Level. Journal of Retailing, 55(4), 35-57.

Lazer, W. (1963). Symbolism and Life Style. In S. A. Greyser (Ed.), Toward Scientific Marketing (pp. 140-149). American Marketing Association, Chicago, II.

Lumpkin, J. R., Greenberg, B. A., \& Goldstucker, J. L. (1985), Marketplace Needs of the Elderly: Determinant Attributes and Store Choice. Journal of Retailing, 61(2), 75-105.

Markus, H., Smith, J., \& Moreland, R. (1985). Role of the self-concept in the perception of others. Journal of Personality and Social Psychology, 49, 1494-1512. http://dx.doi.org/10.1037/0022-3514.49.6.1494 
McCracken, G. (1989). Who is the Celebrity Endorser? Cultural foundations of the endorsement process. Journal of Consumer Research, 16(3), 310-321. http://dx.doi.org/10.1086/209217

Mitchell, V. W., \& Walsh, G. (2004). Gender Differences in German Consumer Decision-Making Styles. Journal of Consumer Behavior, 3(4), 331-346. http://dx.doi.org/10.1002/cb.146

Pol, L. G. (1991). Demographic contributions to marketing: An assessment. Journal of the Academy of Marketing Science, 19(1), 53-59. http://dx.doi.org/10.1007/BF02723424

South, S. J., \& Spitze, G. (1994). Housework in marital and non-marital households. American Sociological Review, 59(3), 327-347. http://dx.doi.org/10.2307/2095937

Sproles, G. B. (1985). From Perfectionism to Fadism: Measuring Consumers' Decision making styles, Proceedings, American Council on Connsumer Interest (pp.79-85).

Srinivas, D., Steven, L., \& Andrews, J. C. (1993). Cross - Cultural Generalizability of a Scale for Profiling Consumers' Decision - Making Styles. The Journal of Consumer Affairs, 27, 5-56.

Wagner, A. K., \& Wedel, M. (1995). Life Style Segmentation with Tailored Interviewing. Journal of Marketing Research, 32, 308-317. http://dx.doi.org/10.2307/3151983

Wansink, B. (2000). New Techniques to Generate Key Marketing Insights. Marketing Research, 12(2), 28-36.

Wedel, M., \& Kamakura, W. A. (2000). Market segmentation: Conceptual and methodological foundations (2nd ed.). Norwell, MA: Kluwer Academic Publishers. http://dx.doi.org/10.1007/978-1-4615-4651-1

Wong, N., \& Smith, J. (2002). College students spend \$200 billion per year. Retrieved March 18, 2012, from http://www.harrisinteractive.com/news/allnewsbydate.asp?NewsID=480

\section{Copyrights}

Copyright for this article is retained by the author(s), with first publication rights granted to the journal.

This is an open-access article distributed under the terms and conditions of the Creative Commons Attribution license (http://creativecommons.org/licenses/by/3.0/). 